\title{
Miejsce standardu burgenlandzkochorwackiego wśród języków indoeuropejskich
}

\author{
ARTuR ŚLĘZAK \\ Akademia Techniczno-Humanistyczna, Wydziat Humanistyczno-Społeczny, \\ Ul.Willowa 2,PL-43-309 Bielsko-Biała,aslezak@ath.bielsko.pl
}

SCN II/2 [2009], 100-106

Jezik gradiščanskih Hrvatov se je razvil iz severozahodnih hrvaških dialektov med 15. in 17. stol., zato gradiščanski Hrvati ob čakavskem in štokavskem narečju govorijo tudi kajkavsko narečje (zahodna Madžarska). Za ta narečja so značilni številni arhaizmi, obogatena pa so tudi z mnogimi neologizmi. Jezik gradiščanskih Hrvatov je standardiziran v obsežni slovnici Gradišćanskohrvatska gramatika (Željezno 2003).

The language of Burgenland Croats was based on Croatian dialects from the 15 to $17^{\text {th }}$ centuries. Native speakers of the standard use three dialects of the Croatian language, mainly Shtokavian and Chakavian, and Kajkavian, in which there are preserved many archaisms and neologisms. The standard of Burgenland Croats was included in the grammar published in Eisenstadt (Gradišćanskohrvatska gramatika, 2003).

Ključne besede: jezikoslovje, narodne manjšine, slovanski jeziki, jezik gradiščanskih Hrvatov, slovnica

Key words: linguistics, native minorities, slavonic languages, the language of Burgenland Croats, grammar

Języki indoeuropejske to te, które się rozprzestrzeniły z terenów Indii do zachodniej Europy i dzięki temu faktowi otrzymały swą nazwę. Jednak to nie przestrzeń jest warunkiem przynależności, ponieważ na tym obszarze istnieją także języki nieindoeuropejskie, np.: węgierski, fiński i estoński, turecki itp. $\mathrm{Z}$ drugiej strony istnieją także języki indoeuropejskie, które rozprzestrzeniły się na tereny daleko wykraczające poza obszar Europy i Azji. Dlatego językami indoeuropejskimi nazywamy wszystkie te i tylko te, które z powodów 
podobieństwa genetycznego uznane zostały za spokrewnione między sobą. Porównując pojedyncze słowa i osobliwości gramatyczne niektórych języków zauważamy, że wykazują one różne stopnie podobieństwa między sobą. W związku z tym dzielimy je na więcej podgrup, do których zalicza się języki narodów słowiańskich.

Języki te wykazują najmniejsze zróżnicowanie zarówno w obrębie leksyki, jak i struktury gramatycznej. Ich wyraźne pokrewieństwo jest wynikiem późnego rozpadu na poszczególne języki. Przypuszcza się, że Słowianie do III wieku n. e. posługiwali się jednym językiem z nieznacznymi różnicami dialektycznymi (Por. Težak, Babić 1996: 9). Ze względu nie tylko na warunki geograficzne, ale i podobieństwo w budowie gramatycznej i słownictwie wyróżniamy trzy grupy języków słowiańskich: zachodnią, wschodnią i południową.

Grupa zachodnia (północno-zachodnia) obejmuje następujące języki: polski, kaszubski, ${ }^{1}$ dolnołużycki, górnołużycki, czeski i słowacki. Do tej grupy należy również wymarły w XVIII wieku język połabski.

$\mathrm{Na}$ grupę wschodnią, najbardziej zwartą o największej liczbie użytkowników, przypadają języki: rosyjski, białoruski, ukraiński, rusiński, łemkowski (Por. Sławski 1988: 909).

Natomiast obszar południowosłowiański, najmniej liczny ze względu na użytkowników rodzimych języków, według najnowszych podziałów, wyróżnia kolejne standardy językowe: serbski, bośniacki, chorwacki, czarnogórski (Zob. szerz. Brom 2007), słoweński, bułgarski, macedoński oraz stanowiący przedmiot niniejszego artykułu: burgenlandzkochorwacki, który z racji swej peryferyjności i wielkiego podobieństwa genetycznego do języka chorwackiego, zazwyczaj nie był ujmowany w tego typu klasyfikacjach. Za południowosłowiański w istocie należy uważać także cyrylo-metodejski język staro-cerkiewno-słowiański, najstarszy język literacki Słowian (Sławski: op. cit., 969-977).

W przypadku tych języków stosuje się jeszcze jeden, wyraźnie różnicujący, podział na dwie części: zachodnią i wschodnią (Por. Stieber 1979: 15-16). Pierwsza z nich obejmuje obszar języ-kowy będący głównie pod wpływem oddziaływania kultury, literatury (język łaciński), sztuki i religii historycznych prowincji Cesarstwa Rzymskiego, druga zaś - Bizancjum. Do zachodniej części zaliczamy dzisiejsze standardy literackie Chorwatów, Słoweńców oraz Chorwatów burgenlandzkich.

Genetycznie język burgenlandzkochorwacki wywodzi się z północno-zachod-nich dialektów chorwackich XV-XVII w. Dlatego dzisiejsi burgenlandzcy Chorwaci posługują się nie tylko narzeczem czakawskim i sztokawskim, ale także kajkawskim. Obecnie zdecydowana większość tzw. kajkawców zamieszkuje tereny zachodnich Węgier (Zob. Sławski 1962: 83-116).

Narzecza burgenlandzkochorwackie charakteryzują się licznymi archaizmami, a jednocześnie są wzbogacone przez wiele neologizmów, które pokrewnym językom południowosłowiańskim przedstawiają się jako obce. Stało się to za

${ }^{1}$ Nie wszyscy językoznawcy uznają kaszubski za odrębny język i traktują go tylko jako silnie archaiczny dialekt języka polskiego. 
sprawą utraty przez chorwackie dialekty - podczas przesiedleń ludności chorwackiej na nowe tereny - w przeciągu stuleci żywego kontaktu z pierwotnym obszarem językowym (macierzą chorwacką), przez co nie dokonał się pełny rozwój języka (Por. Ernst: op. cit., 250).

Podobnie jak w Chorwacji, tak i w burgenlandzkiej diasporze widoczne są znaczne różnice wewnątrzdialektalne. Standardowy język burgenlandzkich Chorwatów ma swój punkt wyjścia i oparcia w mówionej czakawszczyźnie ikawsko-ekawskiej (por. realizacja prasł. jat'); jest pod wyraźnym wpływem języka niemieckiego i węgierskiego oraz w nieznacznym stopniu słowackiego. Oddziaływania te nie ograniczają się jedynie do leksyki, ale również silnie zaznaczają się w strukturach składniowych i fonetyce (Zob. Neweklowski 1969: 94-115) mamy do czynienia z ikawsko-ekawską realizacją prasłowiańskiego jat', która jest najbardziej charakterystyczna dla części środkowej dialektu czakawskiego.

W większości przypadków *ě dało $i$ : por. bižat, človik, dite, divičica, gri, mišat, Nimac, pinezi, ripa, sidit, snig, sime idt. W niektórych przypadkach realizacją *ě jest e: por. biela (powstałe od bela), blied (od bled), brieza, briest, ciela, ciesta, died, dielo, lieto, sieno, stiena, susied, tiesto, zviezda, želiezo itd (Por. Težak, Babić 1995: 20-22).

W miejsce dawnej samogłoski ě mamy dyftong, który rozwinął się dopiero później i nie ma nic wspólnego z narzeczem jekawskim.

Bardzo charakterystyczne jest to, iż przed spółgłoskami przedniojęzykowymi twardymi $s, z, t, d, l, r, n$ pojawia się regularnie samogłoska $e$ (niekiedy też pisane je, ije), we wszystkich innych przypadkach wystepuje $i$. Odstępstwa od tej reguły wystepują w języku gradišćanskochorwackim z powodu zapożyczeń z języka chorwackiego (Zob. Jakubinskij 1925: 381-382). I tak na początku wyrazu $i<\check{e} \mathrm{z}$ protezą $j:$ jisti, jilo; $i<\check{e} \mathrm{w}$ wygłosie por. np.: doli, dvi, gori, nagli, nutri, vani; $i<\check{e}$ przed $g, k$, $h$ por.: big, brig, človik, crikva, grih, oblikal, vlikli, mliko, nikoliko, niki (obok neki), orih, prik, sikira, sikli, smih, snig, uvik i usevik (obok uvek) itd.

Odnośnie wpływu języka słowackiego (Zob. Kučera 1971) nie zauważa się znaczących różnic pomiędzy mową Chorwatów w Burgenlandzie a tych zamieszkujących okolice Bratysławy. Największe istotne zróżnicowanie występuje w Hrvatskim Grobie. Narzeczem jakim się posługuje ta niewielka społeczność uważa się za kajkawskie (Zob. Neweklowski 1978) i faktycznie nosi ono niektóre cechy tego dialektu, por. np.: vujna, vujček, bubit, kon, iščem, melin i lef (tylko te dwa ostatnie leksemy mają $e$ zamiast $a$ ). Pozostałe elementy tej gwary posiadają typowe cechy dialektu czakawskiego, oprócz nielicznych, których nie można zaliczyć do kajkawizmów; por. np. sztokawskie: dim i blato. W rzeczowniku rodzaju żeńskiego występuje końcówka -om, która jest również charakterystyczna dla dialektu sztokawskiego.

Oprócz typowych cech, dialekt posiada również takie, które sprawiają kłopot w zakwalifikowaniu, np. nie dokonała się jotacja, por.: pohadjati, kratji zamiast 
pohađati, kraći. Przez co stwarza się wrażenie, że burgenlandzcy Chorwaci posługują się mową czakawsko-kajkawsko-sztokawską.

$\mathrm{Z}$ racji bliskości genetycznej obu języków oraz oddziaływania kultury słowackiej, a także znacznego oddalenia od macierzy oraz braku organizacji społeczno-kulturowych, chorwaccy przybysze ulegli w krótkim czasie w znacznym stopniu nieuchronnej asymilacji.

Część Chorwatów, która pozostała na Węgrzech nie jest łatwa do zdefiniowania, ponieważ w wyniku powojennych stosunków byli oddzieleni od Burgenlandu i przez to mniej dostępni (Por. Breu 1970). Najbardziej interesującą dla badaczy języka jest społeczność osady Vedešin (Hidegseg) znajdującej się niedaleko Szopron. Określa się ich jako kajkawców ze Slawonii. Tymczasem gwara jaką się posługują nie pozwala na wysunięcie jednoznacznych wniosków co do pochodzenia jej użytkowników. Cechuje ją bowiem sporo czakawskich elementów, a wokalizacja nie przypomina tej z sąsiednich (poljanskich i dolinskich) czakawskich osadach. Realizacją prasłowiańskiego jat’ było $e$, które wydłużone, razem z dawną samogłoską $e$, uległo dyftongizacji i przekształciło się w ej, por. np.: mejšam, mrejt, nejmški, s tejm, mejsu, tersej, itp. Realizację krótkiego jat' wykazuje dzisiaj: vjeter, djelat, rjepa, itp. Podobne zjawisko wystąpiło w przypadku długiej samogłoski o, która przeszła w ou, por. np.: vouže (uže), pout (put), mouš (muž), mouka (muka, brašno); krótkie o natomiast w uo, por.: vuodu, luočest, uluovjeni, puoje, itp.

$\mathrm{W}$ miejsce zgłoskotwórczego $r$ występuje grupa er por. np.: vert, verč, pomervu, vugerski, hervacki, itp.

$\mathrm{Na}$ wyraźne pokrewieństwo z burgenlandzką czakawszczyzną wskazują zjawiska:

- duża ilość ikawizmów (por. np.: driva, razumimo, ulipit, vrime, itp.),

- dźwięczność przed sonantami; por. np.: tag je (tak je), doz je, dičag nam,

- ubezdźwięcznienie przy $k$, por. np.: crikfa, takfa, merkfa, itp.,

- stopnie wyższe przymiotnika, por. np.: mlaji, čemernije, itp.,

- leksyka, por. np.: čuda (mnogo), sakorački (svakakvi), kade, muotinka, denas, jedinajs, legjecejnu (lagljeceno, jeftino), itp.,

- formy czasu przyszłego, por. np.: ču vam poviedat, čemo verč, čemo pout jednuč (poći ćemo jednoč), itp. (Por. np.: Neweklowski 1995: 431-459).

Analizując wpływy niemieckie na język burgenlandzkochorwacki, nie mamy na uwadze niemiecki język literacki, lecz jego dolnoaustriackie i styryjskie narzecza. W okresie osiedlania się ludności chorwackie na terenie Burgenlandu i w pobliskich prowincjach, niemieckiego języka w dzisiejszym rozumieniu nie było. Prawie w tym samym czasie Marcin Luter rozpoczął kłaść podwaliny pod jednolitą wersję literackiego języka niemieckiego, który obejmie przestrzeń od Austrii i większej części Szwajcarii po Morze Północne (Zob. Szulc 1988: 808-809). Język Lutra powoli docierał do Wiednia i okolic. Trzeba pamiętać, że Chorwaci żyli przeważnie w wioskach i nie mieli częstego kontaktu z wykształconą częścią ówczesnego społeczeństwa. 
Oddziaływanie języka niemieckiego na burgenlandzkochorwacki narodowy i literacki język jest ogromny i ma swój znaczący udział w tworzeniu się: nowej leksyki (por. np.: prik dati = übergeben, van zgledati = aussehen), form gramatycznych, np. strony biernej (por. np.: muži su pozvani postali = die Männer sind gerufen worden) oraz na strukturę zdania np. warunkowego, por. np.: Ako to razgledam tako se načuditi ne moremo. Jeśli np. w słowie fieti (gotov) w wygłosie nie ma spółgłoski (fertig), wówczas tej zmiany dokonali Austriacy, a nie Chorwaci. Labialne samogłoski $\ddot{o}$ i $\ddot{u}$ powstały pod wpływem niemieckiego; i tak w niektórych osadach dielat brzmi dölat, a pondiljak-pondüljak.

W mowie dolnoaustriackich Chorwatów w zakresie fonetyki występują właściwości austriackich dialektów: por. np.: glijk (Glück), müli (Milch), tabaj (dabei), prauhat (brauchen), šuidl (Schuh), itp. Ciekawym zjawiskiem jest pomimo że Chorwaci rozróżniają dźwięczne i bezdźwięczne spółgłoski bardzo wyraźnie - przejmowanie niemieckich leksemów bez tego rozróżnienia: por. np.: nempaj-nebenbei.

Wraz z zapożyczeniami leksykalnymi idą w parze i syntaktyczne germanizmy por. np.: visit ostat (zapeti, hängenbleiben), đedan je ovdje biu (einer war da, netko je bio ovdje), uon je pied liet star (er ist fünf Jahre alt).

Często przyjmują się nowe wyrażenia słyszane w języku niemieckim, ponieważ nie próbowano stworzyć własnych odpowiedników, względnie dokonać przekładu na własny język. Dlatego nie należy się dziwić takim tworom językowym jak, por. np.: hajpcat (poluvrijeme, Halbzeit), ersoc (nadomjestak, Ersatz), rignšiam (kišobran, Regenschirm), špuotploc (igralište, Sportplatz). Czasami nacisk obcego wyrażenia jest tak silny, że wypiera stare słowa będące wcześniej standardem, por. np.: frpaj (prošlo, vorbei), gifta se (ljuti se, giftet sich), lajdat (trpjeti, leiden), prauham (trebam, brauchen), raufang (dimnjak, Rauchfang), štot vodie (umjesto, statt), štrajtat (svađati se, streiten) (Por. Brabec 1966).

$\mathrm{Z}$ racji bezpośredniego sąsiedztwa i wzajemnych kontaktów z niemieckojęzyczną ludnością, możemy język burgenlandzkochorwacki porównać z językami dolno- i górnołużyckim oraz językiem kaszubskim, niezależnie od tego, czy ten ostatni traktujemy jako język, czy też jako dialekt. Stanowią one ostatnie relikty języków i dialektów słowiańskich, które się kiedyś rozprzestrzeniały aż po Dolną Saksonię, a między nimi znajdowały się już dzisiaj wymarłe języki: połabski i słowiński wraz z narzeczami (Por. Sławski 1988: 915-934).

Znamienne jest to, że pomimo widocznych granic pomiędzy sztokawskim południem a czakawskim środkowym i północnym Burgenlandem, nie rozwinęły się dwa warianty literackiego języka burgenlandzkiego - jeden dla sztokawskich terenów na południu, a drugi dla czakawskiej północy - tak jak to miało miejsce w przypadku łużyckich Serbów.

Nie bez znaczenia pozostaje fakt nazywania języka burgenlandzkochorwackiego przez samych użytkowników, którzy określają go jako język chorwacki (hrvatski jezik), a z kolei chorwacki język literacki nazywają hrvaćanski (Zob. Benčić 1972: 23). 
Dzisiejsze obszary, na których używa się języka burgenlandzkochorwackiego to dawniej przede wszystkim historyczny Burgenland (ch. Gradišće), ${ }^{2}$ a dziś głównie austriacki kraj związkowy o tej samej nazwie oraz zachodnie Węgry (okolice Kőszeg, Szombathely i Sopron), południowo-zachodnia Słowacja (okolice Bratysławy), wschodnia część Dolnej Austrii i południowe Morawy należące obecnie do Republiki Czeskiej, gdzie jeszcze wśród niewielu zamieszkujących tam chorwackich rodzinach zachował się rodzimy język w różnych wariantach dialektalnych. Mniejsze skupiska można spotkać we Wiedniu i w nielicznych diasporach w Ameryce Północnej i Południowej.

Ostatecznym ugruntowaniem swojej, niekiedy mocno zagrożonej, pozycji wśród standardów indoeuropejskich było dla języka burgenlandzkich Chorwatów ukazanie się w 2003 roku w Eisenstadt (Željezno) pod red. I. Sučića monumentalnej Gramatyki gradišćanskohrvarskoga jezika, co jednocześnie stanowiło zwieńczenie wieloletnich prac normatywnych.

\section{BIBLIOGRAFIA}

J. BREU, 1970: Die Kroatensiedlung im Burgenland und in den anschliessenden Gebieten. Wien.

P. BROM, 2007: Czarnogórski standard wobec różnicowania językowego poludniowej Stowiańszczyzny. Bielsko-Biała.

N. BENČIĆ, 1972: Abriss der geschichtlichen Entwicklung der burgenländischkroatischen Schriftsprache. Wiener Slavistisches Jahrbuch, t. 17. Wien.

I. BRABEC, 1966: Govor podunavskih Hrvata u Austriji. Hrvatski dijalektološki zbornik II. Zagreb.

L. JAKUBINSKIJ, 1925: Die Vertretung des urslav. ě im Čakavischen. Zeitschrift für slavische Philologie I.

Leipzig. 381-382.

K. KUČERA, 1971: Hrvati u Slovačkoj. Kalendar Matice iseljenika Hrvatske. Zagreb.

G. NEWEKLOWSKI, 1969: Die kroatischen Mundarten in Burgenland. Wiener Slavistisches Jahrbuch, T. 15.

--, 1978: Die kroatischen Dialekte des Burgenlandes und der angrenzenden Gebiete. Wien: Österreichische Akademie der Wissenschaften.

${ }^{2}$ Na mocy umowy państwowej z Saint-Germain z dnia 10 września 1919 r. Burgenland. został utworzony z zachodnich części komitatów Pressburg, Wieselburg, Ödenburg i Eisenburg. Określenie to pochodzi od powtarzającej się sylaby końcowej -burg w nazwach wszystkich tworzących go komitatów. 
- -, 1995: Hrvatska narječja u Gradišću i susjednim krajevima. Povijest i kultura gradišćanskih Hrvata. Red. I. Kampuš. Zagreb. 431-459.

A. SZULC, 1988: Języki germańskie. Języki indoeuropejskie. Pod red. Leszek Bednarczuk, t. 2. Warszawa.

F. SŁAWSKI, 1962: Zarys dialektologii południowosłowiańskiej z wyborem tekstów gwarowych. Warszawa, 83-116.

F. SŁAWSKI, 1988: Języki słowiański. Języki indoeuropejskie. Tom 2. Pod red. Leszek Bednarczuk. Warszawa.

Z. STIEBER, 1979: Zarys gramatyki porównawczej języków słowiańskich. Warszawa.

S. TEŽAK, S. BABIĆ, 1995: Gramatika hrvatskoga jezika. Priručnik za osnovno jezično obrazovanje. Zagreb.

- -, 1996: Gramatika hrvatskoga jezika. Priručnik za osnovno jezično obrazovanie. Zagreb.

\section{MESTO STANDARDNEGA JEZIKA GRADIŠČANSKIH HRVATOV MED INDOEVROPSKIMI JEZIKI}

Po najnovejših spremembah v razvoju jezikov imajo južnoslovanski jeziki (njihovo skupno izhodišče je stara cerkvena slovanščina) naslednje standarde: srbski, bosanski, hrvaški, slovenski, bolgarski, makedonski in jezik gradiščanskih Hrvatov; slednji glede na svojo obrobnost in velike podobnosti s hrvaškim jezikom praviloma ni bil upoštevan niti v najnovejših razvrstitvah.

Standardni jezik gradiščanskih Hrvatov se je normiral kot nadnarečna tvorba severozahodnih hrvaških dialektov, ki so se govorili med 15. in 17. stoletjem - čakavščina, štokavščina in kajkavščina. Standardni jezik gradiščanskih Hrvatov je v največji meri uzakonil govorjeno podobo ikavsko-ekavske čakavščine, ostaja pa pod močnim vplivom nemškega in madžarskega jezika, deloma tudi slovaškega.

Standardizacija jezika je ohranila številne arhaizme, v knjižnem sistemu pa so opazni tudi neologizmi in slavizacija jezika, kar je predstavljeno tudi v slovnici Gradišćanskohrvatska gramatika (Željezno 2003). Podobno kot na Hrvaškem so tudi v gradiščanski diaspori opazne precejšne dialektalne razlike. 